\title{
ОПРЕДЕЛЕНИЕ ПРОНИЦАЕМОСТИ ТЕРРИГЕННЫХ КОЛЛЕКТОРОВ ПО МАТЕРИАЛАМ ГЕОФИЗИЧЕСКИХ ИССЛЕДОВАНИЙ СКВАЖИН
}

Шнурман И.Г.

(ОOО «НК "Приазовнефть»)

\section{Резюме.}

Представлено обоснование многомерной статистической связи для определения проницаемости терригенных коллекторов в условиях предельного насыщения по материалам промыслово-геофизических исследований.

Определение одного из важнейших параметров продуктивнбгх терригенньгх коллекторов - пронищаемости по материалам геофизических исследований скважин (ГИС) является сложной проблемой. Как правило, оценку преимущественно, абсолютной проницаемости, проводят по парным и многомерным эмпирическим зависимостям, связываюшим ее с геофизическими параметрами или с глинистостью, пористостью, объемной плотностью и другим, определяемым геофизическими методами.

В докладе рассмотрены возможности таких оценок на примере чокракских продуктивных коллекторов Западно-Кубанского прогиба (ЗКП).

В чокракских отложениях преобладают слабо карбонатные (Ккарб $\sigma_{\mathrm{cp}} \approx 2 \%$ ), умеренно глинистые $($ Кгл $=8.4 \%$ ) поровые коллекторы. Их пористость изменяется от 19 до $32 \%$, проницаемость от единиц до 2200 мд, при средних значениях $27 \%$ и 266 мд. Глинистый материал, являясь цементом в поровом пространстве коллекторов, существенно влияет на их фильтрационные и емкостные свойства. По данным ГИС удельные электрические сопротивления продуктивнњх песчано-алевритовых прослоев в зависимости от их глинистости изменяются от 5-6 до 100 и более Омм, для них характерно понижающее проникновение.

Технология определения проницаемости по данным ГИС обоснована по материалам петрофизических исследований керна. При этом изучались эмпирические зависимости проницаемости Кпр от пористости Кп, плотности $\delta_{\text {п }}$, глинистости объемной

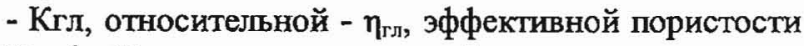
Кпэф. Установлено, что наиболее тесными статистическими зависимостями являются Кпр $=\mathrm{f}\left(\eta_{\mathrm{r.s}}\right)$ и Кпр=f(Кпэф) которые аппроксимируются следующими выражениями [1]:

$$
\begin{aligned}
& \operatorname{Lg}(\text { Кпр })=3.6-6.4 \cdot \eta_{\text {гл }} \\
& \operatorname{Lg}(\text { Кпр })=4.72 \cdot \operatorname{Lg}(\text { Кпэф })-3.68
\end{aligned}
$$

Тем не менее, при оценке проницаемости по этим зависимостям средние относительные погрешности составляют $40 \%$ и более.

В зарубежной практике пироко используются многомерные статистические связи проницаемости с пористостью и связанной водонасьпенностью (Кво), полученные для пластов находяшихся выше переходной зоны [2].

Связанная водонасыщенность Кво зависит от размера пор коллекторов и имеет тенденцию роста при скихении их проницаемости.

Уравнение для определения проницаемости по пористости и связанной водонасышенности может быть представлено в следующем общем виде:

$$
\operatorname{Lg}(\mathrm{Kmp})=\alpha \cdot \operatorname{Lg}\left(\mathrm{K}_{\Pi}\right)+\beta \cdot \operatorname{Lg}\left(\mathrm{K}_{\mathbf{B O}}\right)+\gamma
$$

По данным петрофизических исследований керна, методом наименьших квадратов для чокракских отложений ЗКП обоснована зависимость

$$
\operatorname{Lg}(\mathrm{Kmp})=3.176 \cdot \operatorname{Lg}(\mathrm{K} \Pi)-1.899 \cdot \operatorname{Lg}(\text { Кво })+
$$

или

$$
\mathrm{K} п \mathbf{p}=3.42 \cdot \mathrm{Kn}^{3.176} / \mathrm{K}_{\text {во }}{ }^{1.899}
$$

Как показали расчеты, по приведенной зависимости проницаемость определяется с наименьшей погрепноостью (около $30 \%$ ).

В настоящее время разработана методика определения пористости по комплексу ГИС основанная на результатах комплексной интерпретации плотностного, нейтронного, акустического, микробокового и других методов каротажа. Связанная водонасыщенность находится по материалам электрического каротажа (бокового, индукционного, БКЗ и других).

Таким образом, на основе обоснованной по экспериментальным данным многомерной статистической зависимости предложен способ определения проницаемости по данным ГИС.

\section{ЛИТЕРАТУРА}

1. Шнурман И.Г. Изучение терригенных коллекторов Предкавказья по результатам геофизических исс.ледований скважин. Краснодар: Просвещение-Юг, 2003. 397 c.

2. Timur, A.: "An investigation of permeability, porosity, and residual water saturation relationships for sandstone reservoirs," The Log Analyst (July - Aug. 1968). 